\title{
URGENCY OF INTEGRATED ASSESSMENT ON DRUGS CRIME (A Study in Purbalingga Regency) ${ }^{\Omega}$
}

\author{
Yusuf Saefudin, Agus Raharjo and Budiono \\ Postgraduate Program Faculty of Law Universitas Jenderal Soedirman \\ E-mail: yusuf.saefudin12@gmail.com
}

\begin{abstract}
The number of drugs trafficking increases as well as the number of drugs addicts and drug abusers. Various rules are formulated to repress the drug abuser and trafficking, one of which is through integrated assessment. The paper explains the philosophy of integrated assessment and implementation of the integrated assessment in Purbalingga Regency. This research is empirical by applying methods of survey, observation, interview and literature review. Data were collected and analyzed qualitatively by descriptive analysis. Based on the research result, integrated assessment is a mechanism designed to differentiate drug abusers and addicts from drug traffickers and also to make treatment plan for the drug addicts and drug abusers. In Purbalingga, integrated assessment has been implemented since 2015. Yet practically several obstacles are identified including assessment request and assessment result is overdue issued, lack of coordination among Integrated Assessment Team, secretary facilities of Integrated Assessment Team is not adequate, infrastructure of rehabilitation place is limited and the programs of rehabilitation do not procedurally run.
\end{abstract}

Keywords: integrated assessment, drugs crime, penal meditation

\begin{abstract}
Abstrak
Jumlah kasus peredaran gelap narkotika terus meningkat seiring dengan meningkatnya jumlah pecandu dan penyalahguna narkotika. Berbagai peraturan dibentuk untuk menekan angka penyalahgunaan dan peredaran gelap narkotika, salah satunya peraturan mengenai asesmen terpadu. Permasalahan yang dikaji dalam penelitian ini yaitu mengenai apa filosofi asesmen terpadu dan bagaimana pelaksanaan asesmen terpadu di Kabupaten Purbalingga. Penelitian ini merupakan penelitian empiri, didesain menggunakan metode survey, observasi, wawancara dan studi pustaka. Data yang diperoleh dikumpulkan dan dianalisis secara kualitatif dengan model deskriptif-analitis. Berdasarkan hasil penelitian, asesmen terpadu merupakan mekanisme yang didesain untuk membedakan antara pecandu dan penyalahguna narkotika dengan pengedar narkotika serta membuat rencana treatment bagi pecandu dan penyalahguna narkotika. Di Purbalingga asesmen terpadu telah dilaksanakan sejak tahun 2015, namun pelaksanaannya dijumpai banyak permasalahan, yaitu: permohonan asesmen dan hasil asesmen keluar melebihi batas waktu, minimnya koordinasi anggota Tim TAT, sarana kesekretariatan Tim TAT belum memadai, sarana prasarana tempat rehabilitasi terbatas dan program rehabilitasi tidak berjalan sesuai prosedur.
\end{abstract}

Kata kunci: asesmen terpadu, tindak pidana narkotika, mediasi penal

\section{Introduction}

Drugs abuse and trafficking demand people concern among law enforrcers and society. Drugs which is basically addressed for medical matters tends to be abused recently. This abuse is harmful thus considered as unlawful. In regard to this, it is urgent to control the use and distribution of this addictive substance by law enforcers. ${ }^{1}$ The use of drugs other than for medical indications, without doctor's recipe is pa-

$\Omega \quad$ This writing is a part of research's result of Thesis compilation titled "Asesmen Terpadu dalam Kasus Tindak Pidana Narkotika dan Implikasinya Terhadap Putusan Hakim Pengadilan Negeri Purbalingga" Master Program of Law Science Faculty of Law Universitas Jenderal Soedirman, Fund source of the research comes from Beasiswa Unggulan Pegiat Sosial dan Seniman Year 2015 with Decree from Head of Planning and International Cooperation Ministry of Education and Culture Number: 5032 A1.4/LL2016. 
thologic and disrupts activities at home, school or college, workplace and social environment. ${ }^{2}$

Chief of National Narcotics Board in press release in the end of year 2016 said that the narcotics abuse and trafficking are extraordinary crime that threatens the world and can be used as a weapon in proxy war to weaken a nation. Therefore, this crime must be eradicated and comprehensively dealt. ${ }^{3}$ Budi Waseso in his press release further stated:

"This year National Narcotics Board reveals 807 narcotic cases and 1,238 suspects are detained with evidence of 2.6 tons of dried marijuana, 20,000 marijuana trees, 16 hectares of marijuana fields; 1,016 tons of methamphetamine; 754,094 ecstasy pills and 568.15 grams of ecstasy; 581.5 grams of heroin; 108.12 grams of morphine; 4.94 grams of cocaine; and 0.32 liters of hashish". ${ }^{4}$

Phenomenal crime must be treated exceptionally. The increasing number of drugs trafficking is in line with the growing number of its addict and abusers. Hence a comprehensive and thorough treatment is needed. The pattern of this crime continuously develops. Through National Narcotics Board, government commit a strict effort in prevention, eradication, and rehabilitation.

One current pattern intensively implemented is to avoid drug addicts and drug abusers from imprisonment and direct them to the treatment instead to recover the physical and psychological conditions. The treatment patterns appear due to the amount of potential worsening of drug addicts and abusers when being imprisoned. Initially they were imprisoned as users, once they were out and then arrested

Muntaha, “Aspek Yuridis Penyalahgunaan Narkotika Di Kalangan Remaja", Jurnal Mimbar Hukum, Vol. 23 No. 1, February 2011, Yogyakarta: Faculty of Law Universitas Gadjah Mada, page 216.

2 Eleanora, Fransiska Noita, "Bahaya Penyalahgunaan Narkoba Serta Usaha Pencegahan dan Penanggulangannya (Suatu Tinjauan Yuridis), Jurnal Ilmu Hukum, Vol. XXV, No. 1, April 2011, Jakarta: Faculty of Law Universitas Mpu Tantular, page. 438

3 National Narcotics Board, Press Release in The End of Year 2016, Kerja Nyata Perangi Narkoba, Jakarta, 22 December 2016, page. 1

4 Chief of National Narcotics Board' Speech in Press Re. lease at the End of 2016, Kerja Nyata Perangi Narkoba. again, they became drug traffickers. This surely cannot be separated from their interaction in prisons which makes drug addicts and users exacerbated.

Drugs abuse has a large and complex dimension, either from medical, psychiatric, mental health, or psychosocial aspect. ${ }^{5}$ Drug addict and abuser are "sick people". Thus the best way to treat them is by recovering them. Drug addict and/or drug abuser are obliged to attend medical treatment by placing them in either medical or social rehabilitation.

The placement of drug addict and abusers into a rehabilitation institution complies with the aim of Law of Drugs as mentioned in Article 4 letter $\mathrm{d}$. Besides, article 127 by observing article 54, 55, and 103 and also Circular Letter of Supreme Court regulation Number 4 Year 2010 on The Placement of Drug Abuse, Victim of Drug Abuse and Drug Addicts into Medical Rehabilitation Institution and Social Rehabilitation can be used as judges' guidance to decide the rehabilitation for drug addicts and drug abusers.

For defendants who are drug-addicted can be asked by the judge to have medical treatment and/or rehabilitation. The word "can", may be defined that judges have no obligation to instruct the defendant to have medical treatment and/or rehabilitation. ${ }^{6}$

Several operational rules are set out to put article governing rehabilitation in Drugs Laws more effectively. The effort to differentiate drug addict and drug abuser from drug traffickers was initiated from the issue of Circular Letter of Supreme Court regulation Number 4 Year 2010 to Joint Regulation of 7 (seven) National Institute (Supreme Court, Attorney General's Office, Ministry of Law And Human Rights, Ministry of Social, Ministry of Health, National Police and National Narcotics Board).

\footnotetext{
Elrick Christoper Sanger, "Penegakan Hukum Terhadap Peredaran Narkoba Di Kalangan Generasi Muda", Jurnal Lex Crimen, Vol. II No. 4, August 2015, Manado: Faculty of Law Universitas Samratulangi, page 5.

6 Saryono Hanadi. "Analisis Putusan Hakim Nomor: 113/ Pid.B/2007/Pn.Pml Tentang Tindak Pidana Penyalahgunaan Narkotika", Jurnal Dinamika Hukum, Vol. 10. No. 1, January 2010 Edition, Purwokerto: Faculty of Law Universitas Jenderal Soedirman, page 12.
} 
To decide someone as a suspect arrested or red-handed by police or National Narcotics Board is conducted through assessment mechanism. The assessment is performed by Integrated Assessment Team (IAT). As mentioned in Common Laws that Integrated Assessment Team is a team that consists of Paramedics and Legal practitioners appointed by Chief of local work force based on National Narcotics Board, Province Narcotics Board, Regency/City Narcotics decree.

Based on media sources, Purbalingga is frequently called as a drugs transit area. Up to present, Purbalingga National Narcotics Board was 4 times successfully revealed the case with 6 suspects. Recently, Purbalingga Narcotics Board onDecember $26^{\text {th }} 2016$ successfully disclose methamphetamine traffic network inside jail. Several revealed cases done by National Narcotics Board of Purbalingga Regency during 2016, most suspects are not domiciled in Purbalingga, only the transaction committed in the territory of Purbalingga.

The handling of drugs crime in Purbalingga Regency through integrated assessment mechanism has implemented since 2015 until present. As the writer became the part of National Narcotics Board of Purbalingga Regency institution, he directly observed how the integrated assessment process was implemented. Hence, the writer attempts to express the urgency of integrated assessment in drugs crime cases by the research in Purbalingga. This research is conducted to know the beginning process of drugs crime cases handling pattern through integrated assessment and to know the process of the implementation of integrated assessment currently implemented in Purbalingga. By doing so, the significance of the integrated assessment in the handling of drugs crime cases is then identified.

\section{Problems}

According to the introduction above, there are two problems which are formulated as follows: first, how is the beginning of integrated assessment in drugs crime cases; second, how is the implementation of integrated assess- ment in drugs crime cases in Purbalingga; third, How is the urgency of integrated assess-ment in drugs crime cases?

\section{Research Methods}

This is an empirical research. To solve the problems, the research is designed by survey, observation, interview and literature review methods. The main sources of this research are primary data and secondary data. Primary data was taken directly from informant through structural and non-structural interview and observation in several related institutions with the implementation of integrated assessment in drugs crime cases. Secondary data came from the documents and other relevant data. The location of this research is in Purbalingga Regency, where the target of this research are law norm and law enforcement process. The informant of the research was purposively selected including the member of Integrated Assessment Team (doctors/paramedics, National Narcotics Board, police, and judge) and Panti Rehabiltiasi Narkoba YPI Nurul Ichsan Al-Islami. There is no limitation in informants since it applied snow ball sampling technique. Then the data were collected and analyzed qualitatively with descriptive-analytic model.

\section{Discussion}

\section{Integrated Assessment in Drugs Crime Cases}

Under the provisions of Article 54 of Drugs Law, drugs abuser and the victim of drug abuse are obliged to have medical rehabilitation and social rehabilitation. For the drug abuser and the victim of drug abuse that stated as suspect or defendant in drugs crime and drugs precursor need a specific treatment by placing them in rehabilitation institution to get medical treatment and rehabilitation for recovery.

Article 13 paragraph (3) Government Regulation Number 25 Year 2011 on Implementation of Compulsory Report of Drug Addicts, Drug Addicts who have judicial process can be placed in Rehabilitation Institution. Drugs Addict and/or Victim of Drug Abuse stated as suspect or defendant on drugs crime during the judicial process need special treatment. This treatment com- 
plies with the effort to protect suspect's rights as regulated in Criminal Code Procedure.

Law enforcement is not something like drawing straight line then can be finished by making laws and implementing as a machine, seemingly simple and easy like automatic machine model. ${ }^{7}$ Since Indonesia's independence, law enforcement has been a main issue in this country. Some unsolved and unfinished big cases causes society's distrust toward law as a means to seek justice. ${ }^{8}$

Stage and Punishment or determination of the criminal punishment is a tool to achieve the goal. In identifying the purpose of concept punishment is from the equilibrium of the two main principals, that are the protection of society and protection or coaching of the suspected criminal. ${ }^{9}$

Related to Punishment Concept, Agus Raharjo said:

"Giving a punishment for the convict of a crime does not not only suffer the convict as introduced by retributive theory with its variations, or an effort to protect the society interest as stated by relative theory, rather, it is more to make punishment that can give a big contribution for suspects crime to realize their fault, to change their behavior and to be agent of change if it is necessary, or it can develop the consciousness to realize as God's creatures who have a degree, solidarity or the ability to control themselves". ${ }^{10}$

To treat the drugs crime cases requires a thorough measure by viewing law aspects as well. We do not only see that drugs crime (include drug abuse) as a serious threat for the society, so the convict should be punished. Seeing

Agus Raharjo, "Prosefionalisme Polisi dalam Penegakan Hukum”. Jurnal Dinamika Hukum, Vol. 11 No. 3, September 2011, Purwokerto: Faculty of Law Universitas Jenderal Soedirman, page 395.

8 Hwian Christianto, "Penafsiran Hukum Progresif dalam Perkara Pidana”, Jurnal Mimbar Hukum, Vol. 23 No. 3, October 2011, Yogyakarta: Faculty of Law Universitas Gadjah Mada, page 480.

9 Barda Nawawi Arief, 2016, Bunga Rampai Kebijakan Hukum Pidana: Perkembangan Konsep Penyusunan KUHP Baru, $5^{\text {th }}$ Printing, Jakarta: Prenadamedia, page 94.

10 Agus Raharjo, Berbagai Jenis Pemidanaan Bagi Pelaku Tindak Pidana Narkotika, Paper, Delivered in Seminar Nasional Mewujudkan Indonesia Bebas Narkoba Melalui Pendidikan Kepramukaan, Purwokerto, May 24 2014 , page 5 . the fact above, we have to pay attention to the protection aspect towards individual. Punishment does not only make them cured, but how to make punishment enables them to make better person.

Rehabilitation is done by the result of assessment. Article 7 paragraph (3) Mutual Laws stated that the medical implementation and/or social rehabilitation as stated in paragraph (1) and paragraph (2) is done according to the result of assessment from Integrated Assessment Team and complies with the regulation. Integrated assessment in drugs crime cases are relevant with the development of handling pattern of drug abuse and narcotics trafficking worldwide. In World Drugs Report 2016 mentioned that:

The excessive use of imprisonment for drug-related offences of a minor nature is ineffective in reducing recidivism and overburdens criminal justice systems, preventing them from efficiently coping with more serious crime. The provision of evidence-based treatment and care services to drug-using offenders, as an alternative to incarceration, has been shown to substantially increase recovery and reduce recidivism. ${ }^{11}$

The statement above showed that jail punishment is not effective for drug addicts and drug abusers. Jail is identical with a place to punish a convict crime and the actor called criminal. ${ }^{12}$ Automatically, that will worsen the condition of drug addict or drug abuser. A jail punishment does not give significant effect to decrease the recidivist and the number of drugs-related crimes. It is more effective by giving treatment to drugs addict and drugs abusers, because it substantially will recover the physical condition and mental condition of drugs addict.

In regard to the punishment concept delivered by Agus Raharjo and UNODC concept in World Drugs Report 2016 on integrated assessment in drugs crime, it can be concluded that

11 United Nation Office of Drugs and Crimes, 2016, World Drugs Report 2016. Vienna: United Nation Office of Drugs and Crimes, page ix.

12 Cristian Meldiny Rambitan, "Tugas dan Fungsi Lembaga Pemasyarakatan dalam Merehabilitasi Anak yang Sedang Menjalani Hukuman", Jurnal Lex et Societis, Vol. 1 No. 2, July 2013, Manado: Faculty of Law Universitas Samratulangi, page 69 . 
integrated assessment is a special formulation planned to answer the development of current community condition. Not only giving the chance to drug addict and drug abusers to get rehabilitation access, integrated assessment also creates integrated criminal justice system. Law enforcement institution (National Narcotics Board, Police, and Prosecutor) coordinate well through Integrated Assessment Team. Thus it can enhance the objectivity in seeing any case . The support from the medical team will convince law enforcer in taking certain decision for the suspect of drugs crime.

\section{The Implementation of Integrated Assessment} in Drugs Crime Cases in Purbalingga Regency

Many law enforcers believe that drugs case is a difficult case and needs extra strength and analysis to cope with. If it is successful, the investigators need to be careful in analyzing the case, so it will not create a mistake in the enforcement process. For example, a suspect who is arrested based on the evidence in the amount above Circular Letter of Supreme Court regulation Number 4 Year 2010, it cannot be indicated as drug courier or courier. Deeper observation about the ownership motive of drugs is necessarily performed and how the relationship of the suspect with the existing drugs network. Or vice versa, do not let a suspect who is arrested with the evidence under Circular Letter of Supreme Court regulation Number 4 Year 2010, but have no chance to have treatment.

Masmudi as Section Chief State Attorney General Criminal of Purbalingga Regency said:

"It is rare that drug couriers do not use the product that they distribute. Mostly, it started from consuming the drugs. Finally, at the worse condition because they have no money to buy drugs, they tried to distribute it. Integrated assessment in drugs crime cases is one step forward in handling the suspect who also become drug addict to be treated like human, by rehabilitation process. That is suspect's rights set in Laws." 13

13 Interview with Masmudi, Section Chief State Attorney General Criminal of Purbalingga Regency on Thursday, February $23^{\text {rd }}$, 2017 in District Court Purbalingga.
What Masmudi stated is suitable with the mission of National Narcotics Board that can be seen in Laws Chief of National Narcotics Regulation Number 11 Year 2014 on How to Treat Suspect and/or Defendant of Drugs Addict and victim of Drug Abuse into a rehabilitation institution Drugs addict and/or Victim of Drugs Abuse who stated as suspect and or defendant in drugs crime during the judicial process needs a special treatment through the placement into rehabilitation process to get medical treatment and rehabilition in recovery process.

Chief of National Narcotics Regulation Number 11 Year 2014 becomes a technical guidance to Drugs Addict and Victim of Drugs Abuse which have no rights and against the laws stated as suspect to have rehabilitation. Chief of $\mathrm{Na}$ tional Narcotics Regulation Number 11 Year 2014 also stated to regulate the implementation of the suspect's placement into rehabilitation institution so it can be effective, transparent, and accountable, based on the recommendation of Integrated Assessment Team.

Integrated assessment team in Purbalingga was established since 2015. A change of the leader in National Narcotics Board of Purbalingga Regency influenced the decree of Integrated Asessment Team. According to Decree Number: Skep/18/I/Ka/Bu.02.03/2017/BNNPJTG on Integrated Assesment Team Purbalingga Regency Level Year 2017 on January 30 2017 arranged by Integrated Assessment Team as follows:

Table 1 Arrangement of Integrated Assesment Team Purbalingga Regency 2017

\begin{tabular}{|l|l|l|}
\hline \multicolumn{1}{|c|}{ Name } & \multicolumn{1}{|c|}{$\begin{array}{c}\text { Position in } \\
\text { Institution }\end{array}$} & $\begin{array}{l}\text { Position in Assess- } \\
\text { ment Team }\end{array}$ \\
\hline $\begin{array}{l}\text { Bagus Wi- } \\
\text { caksono, } \\
\text { S.Kom. }\end{array}$ & $\begin{array}{l}\text { Chief of BNNK } \\
\text { Purbalingga }\end{array}$ & Chief \\
\hline Turijandi & $\begin{array}{l}\text { Chief of Eradica- } \\
\text { tion BNNK Purba- } \\
\text { lingga }\end{array}$ & $\begin{array}{l}\text { Member of Law } \\
\text { Team }\end{array}$ \\
\hline $\begin{array}{l}\text { Senentyo, } \\
\text { S.H. }\end{array}$ & $\begin{array}{l}\text { Kasat Narkoba } \\
\text { Polres Purbaling- } \\
\text { ga }\end{array}$ & $\begin{array}{l}\text { Member of Law } \\
\text { Team }\end{array}$ \\
\hline $\begin{array}{l}\text { Masmudi, } \\
\text { S.H. }\end{array}$ & $\begin{array}{l}\text { Kasi Pidum Keja- } \\
\text { ri Purbalingga }\end{array}$ & $\begin{array}{l}\text { Member of Law } \\
\text { Team }\end{array}$ \\
\hline $\begin{array}{l}\text { Dra. Hani } \\
\text { Yuhaeni }\end{array}$ & $\begin{array}{l}\text { Social Supervisor } \\
\text { Correctional } \\
\text { Centers Class II }\end{array}$ & $\begin{array}{l}\text { Member of Law } \\
\text { Team }\end{array}$ \\
\hline & Purwokerto & \\
\hline
\end{tabular}




\begin{tabular}{|l|l|l|}
\hline $\begin{array}{l}\text { dr. Puspi- } \\
\text { tasari }\end{array}$ & $\begin{array}{l}\text { General Doctor } \\
\text { of RSUD Goeteng } \\
\text { Tarunadibrata }\end{array}$ & $\begin{array}{l}\text { Member of Medical } \\
\text { Team }\end{array}$ \\
\hline $\begin{array}{l}\text { Kurniasih } \\
\text { Dwi P, M. } \\
\text { Psi. }\end{array}$ & $\begin{array}{l}\text { Clinical Psycho- } \\
\text { logist of RSUD. } \\
\text { Goeteng Taruna- } \\
\text { dibrata }\end{array}$ & $\begin{array}{l}\text { Member of Medical } \\
\text { Team }\end{array}$ \\
\hline $\begin{array}{l}\text { Wahyu Eni } \\
\text { Pujiastuti }\end{array}$ & $\begin{array}{l}\text { Chief of Reha- } \\
\text { bilitation BN NK } \\
\text { Purbaling-ga }\end{array}$ & $\begin{array}{l}\text { Administration } \\
\text { Officer }\end{array}$ \\
\hline $\begin{array}{l}\text { Awan Pata- } \\
\text { ma, S.IP. }\end{array}$ & $\begin{array}{l}\text { Counselor Reha- } \\
\text { bilitation Section } \\
\text { BNNKPurbalingga }\end{array}$ & Verification Officer \\
\hline
\end{tabular}

Based on data obtained from Polres Purbalingga and National Court Purbalingga, Drug crimes happened during 2016 were 14 cases, added by 1 cases handled by BNN Central Java Province, so there are 15 Drugs Crime Cases. ${ }^{14}$ From the previous total amount, assessment was done to 10 cases as portrayed in the following diagram.

\section{Diagram 1:}

Percentage of Drugs Crime Cases that is assessed and not assessed 2016

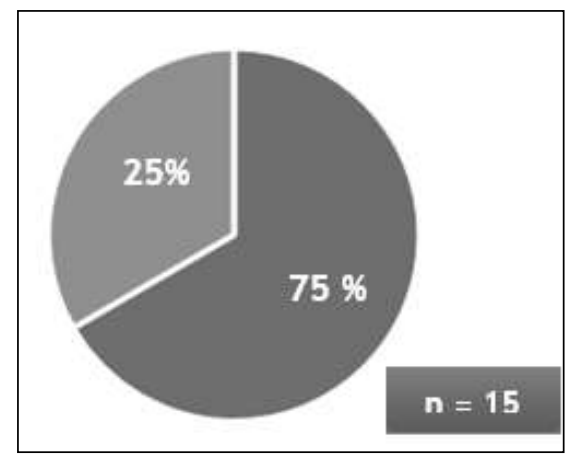

The discussion of this study focused on drugs crime done the assessment. There is different opinion on who can be assessed in the body part of Integrated Assessment Team. According to Senentyo state, the condition of suspect that can be assessed is drugs addict, abuser and the victim of drug abusers while drugs courier/ courier cannot. ${ }^{15}$ In fact, those things have not been conducted by Purbalingga Police. Almost

14 Interview with Senentyo, The Chief of the narcotics unit of the Police Purbalingga Regency, on February 162017 and the result of data obtaining during research process in National Court Purbalingga.

15 Interview with Senentyo, The Chief of the narcotics unit of the Police Purbalingga Regency, on February $16^{\text {th }}$ 2017. all of drugs crime cases handled by Polres Purbalingga was assessed. As Masmudi stated:

"Integrated assessment is meant to separate drug courier and the drug users since drug addict and drug users should be placed in rehabilitation, and for drug courier must go to the jail. So, it needs assessment to make differentiation for users or couriers." 16

Masmudi preferred the case is treated by assessment. Thus, it role in crimes can be identified. On the other hand, Wahyu Eni and Kurniasih stated that those that can be done by assessment are the real drugs addict and drugs abuser or not involved in drugs network. Kurniasih said:

"During this time, thing that I assessed is suspect who arrested with the evidence under the Circular Letter of Supreme Court regulation Number 4 Year 2010. For example, if methamphetamine is under 1 gram. If it is more, I will reject for assessment."17

\section{Wahyu Eni said:}

"Related to the potential one to be assessed is still unclear. Chief of Rehabilitation Sector said that who can be assessed is purely Article 127, while Chief of Eradication said that everyone can be assessed. But if we see Circular Letter of Supreme Court regulation Number 4 Year 2010, it refers to the one who violate pure Article 127, not related to another article. I am convinced. Yet all those cases are treated by assessment." 18

The lack of understanding in Integrated Assessment Team can be seen in several cases. Sometimes, the assessment is necessarily done but it is not and vice versa due to the poor coordination among related parties and te absence of relevant regulation. For instance, Abdullah case. According to the result of assessment, Ab-

16 Interview with Masmudi, Section Chief State Attorney General Criminal of Purbalingga Regency, February $23^{\text {rd }}$ 2017 in National Court Purbalingga.

17 Interview with Kurniasih Dwi P., Phycologist RSUD. Goeteng Tarunadibrata Purbalingga, on February $9^{\text {th }} 2017$.

18 Interview with Wahyu Eni, Chief of Rehabilitation, National Narcotics Board of Purbalingga Regency, on February $9^{\text {th }} 2017$. 
dullah was arrested with the evidence 12.36 gram methamphetamine.

Circular Letter of Supreme Court regulation Number 4 Year 2010 mentioned 5 conditions to get the rehabilitation decision, there are: first, Defendant is arrested with evidence; second, The evidence of the use in a day is found when they are arrested; third, Laboratory test shows positively using drugs; fourth, Certificate from psychiatrist; fifth, It is not involved in narcotics trafficking.

Seeing the different opinions, the wwriter believes that assessment is applied in every case of drugs crime, without any exception. It means that prior to the file submitted from investigator to the Prosecutor, suspect has to be assessed first. It is based on the following considerations: first, Every drugs addict or users are certainly involved in drugs networking, although only in trading process; second, Considering cases happened in Purbalingga, the suspect involved in drugs crime also the users; third, Integrated Assessment Team consists of several law enforcer added by doctor team, so the mistake can be minimized in process making of Investigation Press Release of Police and claim by Prosecutor; fourth, Integrated assessment allows the revelation of a network be-cause there are psychologists who are able to assess the psychological state of the suspect. Hence, lie can be detected.

Law enforcers admit the regulation on integrated assessment is still untidy and not synchronous between one to another. This makes the law enforcer seems to be 'confused' in every stage of implementation. Several regulations related to assessment and rehabilitation that have been made in the implementation are still not optimal. tioned:

Article 7 paragraph (1) PERBER men-

For prisoner included in Drugs Addict and Victim of Drugs Abuser category, and not a drug courier or courier or producer can have medical rehabilitation and/or social rehabilitation that is done in prison and/or medical rehabilitation institution and/or rehabilitation recommended by Government.
The fact shows there is still pure drug addict or drug user caught by BNN Purbalingga Regency that is placed in prison without accepting the treatment. For example, by initial "AS". AS in interview with the writer stated that he is a drug addict or drug user caught by BNN Purbalingga Regency on May $25^{\text {th }} 2016$ with the evidence 0.51 gram methamphetamine. AS said:

"I was caught by BNN Purbalingga when I was in Bukateja. When I was going to take the goods (methamphetamine) in side way, suddenly the people caught me. At that time, I was offered rehabilitation, but he said the fee was expensive and I had no money, so I choose to be imprisoned."19

Surprisingly, he is purely as a drugs user and right now is in prison without getting special treatment there. AS decision to choose to be imprisoned is caused by the information from BNN Purbalingga Regency's person that rehabilitation is costly. Thus, when he is asked in the court AS preferred being imprisoned because he cannot afford it. Statement of BNN person stating that rehabilitation is expensive is agreed by Chief of Rehabilitation. Wahyu Eni said:

"There is no cost for rehabilitation in 2016. In 2015 we could send people to lido to get rehabilitation freely because the program in that year provided rehabilitation for the drugs addict. But in 2016 we have no budget for it, even Integrated Assessment Team have no budget in 2016."20

BNN should make new regulation that is not against the previous regulation. There should be a program synchronization in every change of the leader. Meanwhile, as one of Institution that accept obligation report, RSUD Goeteng Tarunadibrata also delivered the same thing as BNN. They have no budget to do rehabilitation, and also for hospitalization. We never handle a patient for hospitalization. Now we only treat people without hospitalization in coor-

19 Interview with AS, Prisoner of Drugs Crime, March $3^{\text {rd }}$ 2017.

20 Interview with Wahyu Eni, Chief of Rehabilitation, National Narcotics Board of Purbalingga Regency, on February $9^{\text {th }} 2017$. 
dination with BNN. We have no budget for hospitalization."21

Yayasan Nurul Ichsan Al-Islami as the social rehabilitation under Ministry of Social Affairs often said that rehabilitation in their place is free but practically not. In that place, every patient has to pay 4 million. The fee according to the manager used to purchase spices and other natural ingredients that are used as a means of therapy. Rehabilitation costs 4 millions here, but it was used to buy herbs and other nat-ural ingredients that are used as a means of therapy. Or if the patients themselves could buy, we allow them to find the needs for themselves". 22

\section{Further, Ichsan said:}

"Free rehabilitation provided is free for meals and for other routine services. As this has been financed by the Ministry of Social Affairs. Social ministries do not endure the cost of drugs, so these costs are charged to the patient". ${ }^{23}$

Those conditions are clearly not in accordance with the regulation expectations. BNN Purbalingga Regency in any counseling also stated on a free rehabilitation programs for drugs addicts and drugs abusers. In fact, free rehabilitation does not apply yet for today, especially in Purbalingga.

Another issue that emerged in the implementation of an integrated assessment in Purbalingga is related to the application procedures for the assessment, the assessment and the outcome of the assessment recommendations are not appropriate as mentioned in Chief of National Narcotics Laws Number 11 Year 2014. According to Article 14 of Chief of National Narcotics Regulation Number 11 Year 2014 mentioned:

1) The application referred to in Article 8 paragraph (3) shall be submitted by the investigator at most $1 \times 24$ (one ti-

21 Interview with Kurniasih Dwi P., Psychologist of RSUD. Goeteng Tarunadibrata Purbalingga, on February $9^{\text {th }}$ 2017.

22 Interview with Ustad Ichsan, Chief of YPI Nurul Ichsan Al-Islami Purbalingga, on March $3^{\text {rd }} 2017$

23 Interview with Ustad Ichsan, Chief of YPI Nurul Ichsan Al-Islami Purbalingga, on March $3^{\text {rd }} 2017$ me twenty-four) hours after the arrests.

2) Integrated assessment team conducted an assessment after receiving the application referred to in paragraph (1).

3) Integrated Assessment Team as referred to in paragraph (2) carry out their duties and provide recommendations on the assessment results in a maximum period of six (6) days to the Investigator to be written report to the local District Court.

The fact encountered during the study period is a request by investigators more than $1 \times 24$ hours after the arrest. The author has examined the files obtained during the research and obtained this following results in table 2 .

According to the recapitulation timing table of integrated assessment in 2016 above, there are some cases that the assessment implementation does not run as it should be. An example the case with the suspect is Sugeng Triono. Sugeng was arrested by the Narcotics Unit Team Polres Purbalingga on February $2^{\text {nd }}$, 2016. Application of the assessment was submitted to the police station BNN on February $3^{\text {rd }}$, 2016, the assessment on February $9^{\text {th }}, 2016$, but the date of assessment results issued by BNN Purbalingga Regency was on February $5^{\text {th }}, 2017$. If we look further, there are irregularities in the case occurred clearly visible and impress their "cheating" in making the assessment recommendations. Recommendation assessments should have been issued by BNN later than 6 days from the date of application.

Bayu Kurniawan, as the investigators commented about the deadline for application for the assessment of $1 \times 24$ hours. According to him, $1 \times 24$ hour time limit is not realistic. When the arrest occurred on the holiday, $1 \times 24$ hours certainly cannot be implemented. ${ }^{24}$

Meanwhile, in the case of Mila Mukmaeni's outcome assessment the recommendations came out 17 days from the date of application of the assessment. Interval of 17 days is very long and obviously gives effect on investigation

24 Interview with Dwi Bayu Kurniawan, Staff of Eradication Badan Narkotika Nasional Kabupaten Purbalingga on February $9^{\text {th }} 2017$. 
Table 2. Time Recapitulation of Integrated Assessment Year 2016

\begin{tabular}{|c|c|c|c|c|c|}
\hline No & Supect & Date of Crime & $\begin{array}{c}\text { Date of } \\
\text { Assessment } \\
\text { Request }\end{array}$ & $\begin{array}{c}\text { Assessment } \\
\text { Implementation }\end{array}$ & $\begin{array}{c}\text { Assessment Outcome } \\
\text { Date }\end{array}$ \\
\hline 1 & Sugeng Triono & February $2^{\text {nd }}, 2016$ & February $3^{\text {rd }}, 2016$ & February $9^{\text {th }}, 2016$ & February $5^{\text {th }}, 2016$ \\
\hline 2 & $\begin{array}{l}\text { - Gunandar } \\
\text { - Ginanjar }\end{array}$ & February $2^{\text {nd }}, 2016$ & February $3^{\text {rd }}, 2016$ & February $9^{\text {th }}, 2016$ & February 5t, 2016 \\
\hline 3 & Ali Safrudin & May $25^{\text {th }}, 2016$ & May $27^{\text {th }}, 2016$ & May $30^{\text {th }}, 2016$ & June $9^{\text {th }}, 2016$ \\
\hline 4 & Mustofa Habib & June $11^{\text {th }}, 2016$ & June $13^{\text {th }}, 2016$ & June $14^{\text {th }}, 2016$ & June $17^{\text {th }}, 2016$ \\
\hline 5 & Dian Anggraeni & August $1^{\text {st }}, 2016$ & August $2^{\text {nd }}, 2016$ & August $8^{\text {th }}, 2016$ & August $8^{\text {th }}, 2016$ \\
\hline 6 & Mila Mukmaeni & September $1^{\text {st }}, 2016$ & September $2^{\text {nd }}, 2016$ & September $6^{\text {th }}, 2016$ & September $19^{\text {th }}, 2016$ \\
\hline 7 & Abdullah & September $1^{\text {st }}, 2016$ & September $2^{\text {nd }}, 2016$ & September $6^{\text {th }}, 2016$ & September $19^{\text {th }}, 2016$ \\
\hline 8 & Danar Safrudin & August $3^{\text {rd }}, 2016$ & August $4^{\text {th }}, 2016$ & August $5^{\text {th }}, 2016$ & August $5^{\text {th }}, 2016$ \\
\hline 9 & Melodi Sofani & August $24^{\text {th }}, 2016$ & August $26^{\text {th }}, 2016$ & September $1^{\text {st }}, 2016$ & September $1^{\text {st }}, 2016$ \\
\hline 10 & $\begin{array}{l}\text { Imam Kadri } \\
\text { Soenarko }\end{array}$ & August $24^{\text {th }}, 2016$ & August $26^{\text {th }}, 2016$ & September $1^{\text {st }}, 2016$ & September $1^{\text {st }}, 2016$ \\
\hline
\end{tabular}

process. This will affect the length of detention carried out by investigators. A similar thing happened in Abdullah's case. Mila and Abdullah is a network of drug couriers.

Other cases have been carried out according to the procedure. An example is Melodi's case. Melodi was arrested on August 24, 2016. Application of assessment dated August 26, 2016 and the assessment carried out on 1 September 2016. Meanwhile, the recommendation came out on September 1, 2016. Seeing the time sequence in accordance with the procedure set out in Chief of National Narcotics Regulation Number 11 Year 2014. Related to the implementation of assessment that is not in accordance with the procedure, Wahyu Eni describes the obstacles that have been experienced. Eni said, they have problems in adjusting schedules among Integrated Assessment Team members, especially doctor team. It is hard to find the time of each individual to meet together, even though team's limited time is 6 days for the recommendation should have been out. ${ }^{25}$ Furthermore, Eni said that generally from the investigators, they asked for an assessment at the 2 nd or $3^{\text {rd }}$ day. There was one case who requested the assessment more than 6 days after the arrest.
The determination of 6 days maximum limit should be a recommendation assessment as it relates to the determination of the detention period. The implementation of arrest authority in the case of narcotic crime carried a maximum of $3 \times 24$ (three times twenty four) hours, since the arrest warrant was received by the investigator and can be extended for a maximum of $3 \times 24$ (three times twenty four) hours. When exceeding $6 \times 24$ hours period, the suspect remains checked and no warrant to make an arrest, the suspect has the right to be immediately released. The determination of the maximum limit of six days must already exist the assessment results intended as related to the detention period. If not guilty of criminal acts alleged, then by law the suspect must be released.

Another thing that was not implemented in accordance to procedure of Chief of National Narcotics Board Regulation is the implementation of a medical assessment. Uni said:

"So far my medical team always turns in carrying out the assessment. Sometimes I myself, sometimes dr. Sari. We carry out the request of $B N N$ and so far I have never done an assessment at the same time with dr. Sari." 26
25 Interview with Wahyu Eni, Chief of Rehabilitation Badan Narkotika Nasional Kabupaten Purbalingga, pada Februari $9^{\text {th }} 2017$.
26 Interview with Kurniasih Dwi P, Psychologistof RSUD. Goeteng Tarunadibrata Purbalingga, on February $9^{\text {th }}$ 2017. 
Relating to the assessment of medical procedures, Article 15 of Chief National Narcotics Board Regulation stated:

1. Assessment referred to in Article 12 paragraph (1) point a, includes:

a. Interview on the medical history, history of Narcotics users, history of treatment and care, psychiatric history, and social and family history of Suspect and/or the Defendant; Observations on the behavior of the Suspect; and physical and psychological examination.

b. Assessment referred to in paragraph (1) shall be signed by at least two (2) members of the Medical Team.

c. The format of the assessment referred to in paragraph (1) is contained in Attachment I, which constitutes an inseparable part of this Regulation.

2. Assessment referred to in paragraph (1) shall be signed by at least two (2) members of the Medical Team.

3. The format of the assessment referred to in paragraph (1) is contained in Attachment I, which constitutes an inseparable part of this Regulation.

The team of doctors in Purbalingga consists of namely 1 (one) physicians and 1 (one) psychologist. If there is one member of the medical team was not present according to the author is clearly contrary to Chief of National Narcotics Board Regulation above. Consequently the results of assessments is not valid because there are some points of interviews which were not conducted. If the assessment is still done by one person, then the result is clearly not in line with the expectations because it was not done by the experts. For example, if the psychologist is not present, the doctor is not authorized to conduct psychological interview of the suspect and cannot make observations of behavior and psychological examination because the doctor does not have the competence and authority to do so.

The medical assessments files the authors investigated during the study showed that the medical examiner is only one person. This is clearly contrary to Article 12 paragraph (1) point $b$. which clearly states that the assess- ment should be carried out and signed by a minimum of 2 people of medical team. Because these provisions are not met, then the results of the assessment that has been issued formally defect. The implication results of Integrated Assessment Team recommendations should not be used as documentary evidence in the trial.

\section{Urgency of Integrated Assessment in Narcotics Crime Cases}

The completion of the criminal case of non-litigation through alternative pathways in addition to the main line, namely litigation. Actually, the existence of these alternative pathways is not acknowledged by the basic rules of criminal procedure law, the Criminal Code, but its presence exists and recognized by the community so it is used as one way to resolve the criminal case. ${ }^{27}$

The system set out the Criminal Code by Mardjono Reskodiputro can be broadly divided into three stages. First, the stage before trial or pre-adjudication; second, the stage of trial or adjudication stage; third, the stage after the court or full-adjudication stage. ${ }^{28}$ During the study, the data found that every case that goes up to the ajudication has a tendency to go to jail. Details regarding these data can be seen in the following diagram.

\section{Diagram 2}

Verdict Against Narcotic Crime Cases in Purbalingga in 2016

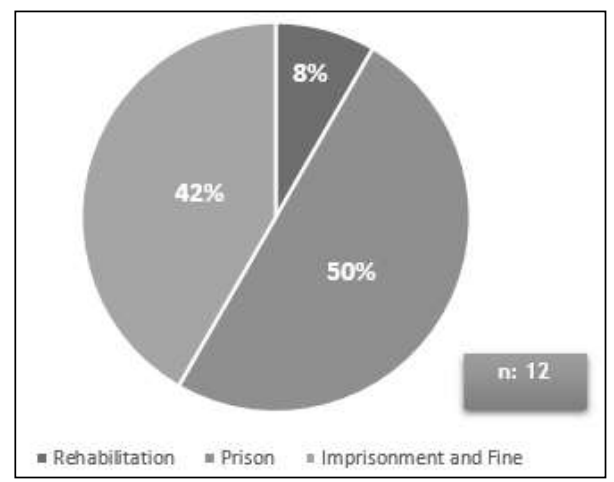

27 Agus Raharjo, "Mediasi sebagai basis penyelesaian Perkara Pidana", Jurnal Mimbar Hukum, Vol. 20 No. 1 February 2008, Yogyakarta: FH Universitas Gadjah Mada, page. 93

28 Mardjono Reksodiputro in Agus Raharjo II, Ibid, page 93. 
Looking at the diagram above, only $8 \%$ or 1 verdict stated to be rehabilitated. As much as $50 \%$ or 6 cases they violated Article 127 was decided imprisonment. Rafli Purbalingga detention officer admitted it.

"In Purbalingga detention center there is no special treatment for drug addicts. All are treated equally. The detention rooms are not placed in a separate block, because we have limited capacity". ${ }^{29}$

Based on observations and interviews during the study, the Purbalingga detention center does not provide special treatment for addicts and drug abusers, and does not separate addicts and drug abusers from couriers or couriers of narcotics. The judge's decision to put addicts and drug abusers in prisons is not made to be good, but it has great potential to be otherwise. In Indonesia there are about 23,779 prisoners are drug users who undergo criminal punishment in prisons. This occurs as a result of drug users was sentenced to a criminal, but rehabilitation penalty is a better choice to be applied for drug users. ${ }^{30}$

Prison is the final process of enforcement of criminal law where prison is expected to carry out the duties and functions as good as possible. ${ }^{31}$ Prisons and detention centers until today is still questionably effective in providing guidance to prisoners, especially prisoners of narcotics. It is certainly not a good achievement for prisons and detention centers. Even still, recently inmates who are undergoing training in a Prison were still able to control crime from inside the prison walls. ${ }^{32}$

Based on the description of the first discussion about the philosophy of integrated as-

29 Interview with Rafli, Purbalingga Detention Officer, on March $2^{\text {nd }} 2017$.

30 Anang Iskandar, "Dekriminalisasi Pengguna Narkoba di Indonesia", Majalah Sinar, Edition I of 2014, Jakarta: Badan Narkotika Nasional, page 15.

31 Kartini S. Hulukati, "Pembinaan Anak Didik Pada Lembaga Pemasyarakatan Khusus Narkotika", Jurnal Pranata, Vol. 4 No. 2, July 2009, Bandung: Faculty of Law Universitas Pasundan, page 98.

32 Haryanto Dwiatmodjo, "Community Based Treatment Dalam Pembinaan Narapidana Narkotika (Studi Terhadap Pembinaan Narapidana di Lembaga Pemasyarakatan Kelas IIA Yogyakarta)", Jurnal Dinamika Hukum, Vol. 14 No. 1 January 2014, Purwokerto: Faculty of Law Universitas Jenderal Soedirman, page 112. sessment, it can be seen how the urgency of an integrated assessment in the case of narcotic crime. Integrated assessment in the case of narcotic crime in line with the spirit of the criminal law reform. Explanation of Article 101 Criminal Procedure Code Plan, adopted the system of sentencing two lines (double track system), where in addition to the offender may be subject to criminal sanctions (criminal punishment), may also be a variety of measures (treatment).

Settlement of the criminal case might be principally carried out within the criminal justice and outside the criminal justice. Settlement done outside the criminal justice means the criminal case has not been reported or brought to the police to avoid police intervention. All control is on the parties. The completion is done within the framework of the criminal justice (police level) which means that the case has been reported or brought to the police and get listed in the register. In this process, the police can act as a mediator or appoint a third party as mediator. ${ }^{33}$

The principle of mediation involves two parties to the dispute. Two disputants are reconciled by presenting a third party. Unlike the criminal cases of drug abuse in which the perpetrator and victim is himself. How can the mediation process be carried out? If the concept is drawn in the case of narcotic crime, then the mediation is carried out simultaneously with the implementation of an integrated assessment. Mediation is done after the assessment results out. Condition is the result of an integrated assessment stated that the suspect is a drug addict or abuser is not involved with the illicit trafficking network of narcotics.

An appropriate mediator in the mediation process is the psychologist who joined the Integrated Assessment Team. Psychologists explore deeper information about the suspect's personality. Mediation is done by reconciling the suspect with himself, assisted by psychologists' role. If there is a genuine commitment from the inside of the suspect to truly recover

\footnotetext{
33 Agus Raharjo, “Mediasi Sebagai...”, op.cit, page 105.
} 
from his addiction, then the commitment to be the result of mediation. It is a treatment that must be lived by addicts or abusers of narcotics.

Indonesian criminal court system does not regulate penal mediation. Therefore, the technical implementation of the results of mediation is conducted by police discretion. One of the Integrated Assessment Team members are from the police. Through legal assessments and medical assessments were carried out, the police investigators determine the role of suspects, medical and psychological conditions. If the result of the Integrated Assessment Team recommendation stated that the suspect is a drug addict or abuser and not involved in trafficking network of narcotics, then the result can be the basis of a strong police exercised discretion. Are the police dare to do so? If this is implemented then it becomes a new breakthrough in the handling of criminal cases of narcotics.

Discontinuation case for the suspects who are addicts or drug abusers by the assessment results will be integrated more effectively than in the processing of cases until the trial which led to imprisonment. In the context of Satjipto Rahardjo progressive law, the law is for human, not human for the law. If the law is for human, ways to pursue happiness need to be developed as part of the human effort to seek justice in the resolution of criminal cases including through non-litigation with this penal mediation. If human for law, then there is an attempt to make human as an object in the process of criminal justice, human actions will be matched with existing law. ${ }^{34}$

It is noteable for law enforcement when the concept of penal mediation through integrated assessment applied, then the law enforcement should really uphold professionalism, integrity and moral values. If that behavior is not practiced, the results of the mediation will be colored by the particular interests of law enforcement officers of the embodiment of the interests of justice.

\section{Conclusion}

${ }^{34}$ Agus Raharjo, “Mediasi Sebagai...”, Op.cit, page 107.
The establishment of Integrated Assessment is as the implementation of Article 154 of Law on Narcotics. Integrated assessment is designed to distinguish drugs addicts and abusers from drug couriers and plan treatment for addicts and drug abusers. The position of integrated assessment of the criminal justice system is new as a breakthrough in the process of law enforcement particularly the case of narcotic crime. Applying integrated assessment is the answer to overcome the problem of drug abuse and trafficking alarming Indonesia in general and Purbalingga in particular.

In Purbalingga, the integrated assessment has been carried out since 2015, but its implementation encountered many problems, including application for assessment and assessment results is issued overdue, lack of coordination of members of Integrated Assessment Team, Integrated Assessment Team secretarial facilities is inadequate, limited rehabilitation center infrastructure and rehabilitation programs do not run ideally. Some of these problems are breakthroughs of law enforcement on the weaknesses of the existing regulations. Accordingly some violation points in integrated assessment in Purbalingga becomes understandable.

Discontinuation case for the suspects who are addicts or drug abusers based on the integrated assessment results would be more effective than processing the case until the court that led to the imprisonment. Discontinuation case can be done by pollicis through the authority discretion according to integrated assessment results.

\section{Suggestion}

Suggestions are formulated as follows: first, It should be added in the Joint Regulations or Chief of National Narcotics Board Regulations about the terms of suspects that can be assessed by considering the setting of MA Circular Letter Number 4 year 2010; second, Assessment arrangements also need to be distinguished the suspect, the assessment for defendant and assessment for inmates since the different stages of the legal process have been undertaken so the technical assessment is also differ- 
ent; third, Technical rules in the respective institutions involved in integrated assessment needs to be synchronized to be more effective.

\section{References}

Arief, Barda Nawawi. 2016. Bunga Rampai Kebijakan Hukum Pidana: Perkembangan Konsep Penyusunan KUHP Baru. $5^{\text {th }}$ Edition. Jakarta: Prenadamedia.;

Badan Narkotika Nasional. Press Release Akhir Tahun 2016. Kerja Nyata Perangi Narkoba. Jakarta. December $22^{\text {nd }} 2016$;

Christianto, Hwian. "Penafsiran Hukum Progresif dalam Perkara Pidana”. Jurnal Mimbar Hukum. Vol. 23 No. 3. October 2011. Yogyakarta: Faculty of Law Universitas Gadjah Mada;

Dwiatmodjo, Haryanto. “Community Based Treatment Dalam Pembinaan Narapidana Narkotika (Studi Terhadap Pembinaan Narapidana di Lembaga Pemasyarakatan Kelas IIA Yogyakarta)". Jurnal Dinamika Hukum. Vol. 14 No. 1. January 2014. Purwokerto: Faculty of Law Universitas Jenderal Soedirman;

Hanadi, Saryono. "Analisis Putusan Hakim Nomor: 113/Pid.B/2007/Pn.Pml Tentang Tindak Pidana Penyalahgunaan Narkotika". Jurnal Dinamika Hukum. Vol. 10 No. 1. January 2010 Edition. Purwokerto: Faculty of Law Universitas Jenderal Soedirman;

Hulukati, Kartini S. "Pembinaan Anak Didik Pada Lembaga Pemasyarakatan Khusus Narkotika". Jurnal Pranata. Vol. 4 No. 2. July 2009. Bandung: Faculty of Law Universitas Pasundan;

Iskandar, Anang. "Dekriminalisasi Pengguna Narkoba di Indonesia". Majalah Sinar. Edition I Year 2014. Jakarta: Badan Narkotika Nasional;

Muntaha. "Aspek Yuridis Penyalahgunaan Narkotika Di Kalangan Remaja". Jurnal Mimbar Hukum. Vol. 23 No. 1. February 2011. Yogyakarta: Faculty of Law Universitas Gadjah Mada;

Noita, Eleanora Fransiska. "Bahaya Penyalahgunaan Narkoba Serta Usaha Pencegahan dan Penanggulangannya (Suatu Tinjauan Yuridis). Jurnal Ilmu Hukum. Vol. XXV No. 1. April 2011. Jakarta: Faculty of Law Universitas MPU Tantular;
Raharjo, Agus. "Mediasi sebagai basis penyelesaian Perkara Pidana". Jurnal Mimbar Hukum. Vol. 20 No. 1. February 2008. Yogyakarta: Faculty of Law Universitas Gadjah Mada;

Raharjo, Agus. "Prosefionalisme Polisi dalam Penegakan Hukum". Jurnal Dinamika Hukum. Vol. 11 No. 3. September 2011. Purwokerto: Faculty of Law Universitas Jenderal Soedirman;

Raharjo, Agus. Berbagai Jenis Pemidanaan Bagi Pelaku Tindak Pidana Narkotika. Makalah. Delivered in a National Seminar to Make Indonesia Free of Drugs through Scout Education, Purwokerto, 24 Mei 2014;

Rambitan, Cristian Meldiny. "Tugas dan Fungsi Lembaga Pemasyarakatan dalam Merehabilitasi Anak yang Sedang Menjalani Huuman". Jurnal Lex et Societis. Vol. 1 No. 2. July 2013. Manado: Faculty of Law Universitas Samratulangi;

Sanger, Elrick Christoper. "Penegakan Hukum Terhadap Peredaran Narkoba Di Kalangan Generasi Muda". Jurnal Lex Crimen. Vol. II No. 4. August 2015. Manado: Faculty of Law Universitas Samratulangi;

United Nation Office of Drugs and Crimes. 2016. World Drugs Report 2016. Vienna: United Nation Office of Drugs and Crimes. 